\title{
Authenticity and Walkability of Iconic Heritage Destination in Bandung Indonesia
}

\author{
Yadi Ernawadi $^{1 *}$, Hariyadi Triwahyu Putra ${ }^{2}$ \\ ${ }^{1}$ Study Program of Management, Faculty of Economics and Bussiness, Universitas Jenderal \\ Achmad Yani, Cimahi, Indonesia \\ ${ }^{2}$ Study Program of Management, Faculty of Economics and Bussiness, Universitas Jenderal \\ Achmad Yani, Cimahi, Indonesia \\ ${ }^{*}$ Corresponding author: \\ Email: yadi.ernawadi@lecture.unjani.ac.id
}

\begin{abstract}
.
This study aims to examine the effect of authenticity and walkability on revisit intention mediated by tourist satisfaction. These four variables are measured using a number of statements on a Likert scale which are confirmed to have completed the validity and reliability tests. Data were collected using a questionnaire which was distributed to 271 respondents based on convenience sampling. Furthermore, the data were obtained and analyzed using structural equation modeling (SEM) and the Sobel test as a basis for hypothesis testing. The results of the hypothesis test explain the rejection of the null hypothesis, which means that there is support for empirical data on the proposed research hypothesis. This illustrates that authenticity and walkability directly affect tourist satisfaction positively and significantly. Meanwhile, revisit intention is influenced positively and significantly both directly by authenticity and walkability and indirectly through tourist satisfaction. Thus, all attributes of authenticity and walkability have a very important role in fulfilling tourists' expectations when appreciating historical buildings in a heritage tourism area. The authenticity attributes of historical buildings that need the attention of relevant stakeholders are historical value, authenticity, originality, and maintenance. Some of the critical elements of walkability that also need to be maintained such as security, comfort, accessibility, connections with other destinations, and pedestrian friendliness for pedestrians.
\end{abstract}

Keywords: Authenticity, walkability, satisfaction, revisit intention, heritage tourism

\section{INTRODUCTION}

Revisit intention can be illustrated as a visitor's willingness to come back to the same destination in the future [1;2]. A key activity for tourism organizers in fostering revisit intention is satisfying them by fulfilling their expectations [3]. According to [4] tourist satisfaction is one important aspect that has a positive effect on revisit intention. In the context of tourism, tourist satisfaction is a comparison of expectations with the perceived performance after traveling to a tourist attraction [5]. Thus, a lot of tourism and hospitality literature in various sectors such as restaurants, hotels, festival events, and others connects the two concepts [6;7]. Meanwhile, tourist satisfaction is http://ijstm.inarah.co.id 
positively influenced by authenticity [8]. This is in line with the research by [9] that suggests authenticity has a significant and positive effect on tourist satisfaction and revisit intention. Authenticity referred to the study explains about originality, purity, and lies outside the commercial scope [10]. Other research results demonstrate that authenticity plays a positive role toward revisiting intention [11;12]. [13] explain the concept of authenticity which is divided into three parts, namely objective authenticity which refers to the originality or authenticity of objects, constructed authenticity or a subjective image of tourists arising from the imagination of an object, and existential authenticity. associated with tourism activities.

In the context that the object of this research is located in an iconic street in Bandung, the comfort of tourists in enjoying the authenticity of the history of the buildings around the location is also important. One of the important contributions in creating the comfort of tourists during their visit comes from the experience of walking in this iconic area. [14] stated that the experience of walking or also known as walkability has not been widely studied based on the perspective of tourists. [15] found a positive relationship between walkability and community satisfaction in a European context where the study was conducted in Austria with a sample size of 834 respondents. In contrast to [14], which examines the relationship between the indicators of measurable tourism success based on the number of tourists and TripAdvisor reviews for a number of major destinations in the UK. The results of their research demonstrate that it is very crucial to pay attention to walkability to encourage the attachment of tourists to the destinations. Based on the researchers' thoughts, walkability can also be argued as one of the variables that influence the satisfaction and revisit intention of the tourists. Meanwhile, [9] argues that revisit intention is not only influenced by authenticity but also tourist satisfaction that mediates both of the variables. By considering several limitations, this study is expected to describe the effect of authenticity and walkability on revisit intention of heritage tourism in Bandung that is mediated by tourist satisfaction. This study involved tourists who were enjoying the scenery alongside Braga and Asia-Afrika areas as the most iconic streets in Bandung.

\section{LITERATURE REVIEW}

[8]defines authenticity as a part of history, and culture, or something that is connected with the past. Authenticity can also be associated as a local distinctiveness associated with social, economic, and environmental characteristics that make this place special, different from others [16]. Thus it can be interpreted that authenticity is a concept that shows the uniqueness of a tourist destination [17]. The perception of tourists about the authenticity of a heritage site is a fundamental factor that determines their decision to visit [18]. Thus authenticity plays a vital role in the heritage tourism 
industry because differences in culture, history, language can make a site different from one another and maintain its originality [17]. There are a number of indicators suggested by [19] to measure authenticity consisting of good building maintenance, buildings representing local history in the past, antique building decoration art, and originality of buildings. According to [8] authenticity has a positive and significant effect on tourist satisfaction.

Satisfaction is a function of pre-purchase expectations and perceived performance after purchasing products and services [20]. [21] defines satisfaction as a feeling of satisfaction or disappointment for someone resulting from a comparison of product performance or results with expectations, if the performance is below expectations, the customer will be disappointed, and if it is in accordance with expectations the consumer will feel satisfied. Meanwhile, tourist satisfaction is defined as the level of positive feelings obtained from the experience of visiting a tourist destination [22]. The indicators that can be used to measure tourist satisfaction consist of the level of feeling happy about the experience, the level of fulfillment of expectations [19], the level of perceived decision accuracy, and the level of overall satisfaction [23]. [13] explains that tourist satisfaction is significantly and positively influenced by authenticity. Likewise, [8], [9], and [19] provide support for [13] stated that authenticity has a positive effect on tourist satisfaction. Apart from authenticity, [14] stated that walkability plays an important role in making tourists feel satisfied with their visit to a tourist destination. Walkability is a multidimensional concept which can generally be defined as an extension of the development environment that allows walking activities [24] and is friendly to pedestrians ([25]; [26]). Referring to [27], walkability in this study will be measured using indicators consisting of traffic safety, connectivity, accessibility, security in terms of crime, and comfort. According to the explanation of the relationship between these variables, the first two hypotheses can be determined as follows:

\section{H1: Authenticity has a positive effect on satisfaction}

H2: Walkability has a positive effect on satisfaction.

Meng \& Han [28] stated that tourist satisfaction has a positive effect on revisit intention. The concept is explained as the willingness of visitors to revisit the same place in the future ([2]; [29]). Meanwhile, [30] defines revisit intention as a form of behavior from previous visit experiences on the quality of destination services in the same place. The indicators that can be used to measure revisit intention consist of a strong desire to come back, the willingness of tourists to visit again with friends and family [23] and willingness to come back if they are around the location [9]. [31] argue that interest in returning to visit can also be measured through the use of services on a sustainable basis, and will buy similar services in the future and recommend them to other parties. Previous research has demosntrated a positive and significant relationship between authenticity and revisit intention ([32]; [11]). Not only influenced by 
authenticity, revisit intention is significantly positively influenced by tourist satisfaction as evidenced in the research of [33] that states tourist satisfaction has a significant and positive effect on revisit intention. Likewise, [34] argues that revisit intention is influenced by tourist satisfaction. Meanwhile, [14] examined the the crital role of walkability and to encourage attachment to tourist destinations. [28] stated that tourist satisfaction has a positive effect on interest in returning to visit. Interest in visiting again is said to be the willingness of a visitor to revisit the same place in the future [2;29]. Meanwhile, [30] defines interest in returning to visit as a form of behavior from previous visit experiences on the quality of destination services in the same place. The indicators that can be used to measure interest in visiting again consist of a strong desire to come back, the willingness of tourists to visit again with friends and family [23] and willingness to come back if they are around the location [9]. [31] argue that interest in returning to visit can also be measured through the use of services on a sustainable basis, and will buy similar services in the future and recommend them to other parties. Previous research has demonstrated a positive and significant relationship between authenticity and interest in returning to visit [28;32]. Not only influenced by authenticity but revisit intention is significantly positively influenced by tourist satisfaction [33]. Likewise, [34] demonstrates that revisit intention is influenced by tourist satisfaction. Meanwhile, [14] stated that walkability is a crucial factor to encourage tourist attachment to the destinations. Based on the explanation above, the third, fourth, and fifth hypotheses are determined as follows:

H3: Authenticity has a positive effect on revisit intention.

H4: Walkability has a positive effect on revisit intention.

H5: Tourist satisfaction has a positive effect on revisit intention.

[9] stated that revisit intention is influenced by authenticity mediated by tourist satisfaction. The study discusses the role of local cultural wisdom in encouraging tourists to travel to Korea, specifically Jidong Village and Murals in Suwon. The finding is in line with the research by [11] that indicates that tourist satisfaction has a mediating effect on the relationship between authenticity and revisit intention. In addition, a combination of the thoughts of [14] and [15] converges on the notion that tourist satisfaction stimulates the effect of walkability on revisit intention in a tourist destination. Based on the explanation of the relationship between these variables, the last two hypotheses are determined as follows:

H6: Satisfaction mediates the effect of authenticity on revisit intention.

H7: Satisfaction mediates the effect of walkability on revisit intention.

\section{METHODS}

The research process is guided by deductive reasoning which aims to test hypotheses with a positive directional format (causal studies) in order to validate the theory. This research approach is quantitative, while the strategy used is a survey. 
There are three variables in this study that were measured through the variable operationalization process using a Likert scale which is designed to examine how strongly the subjects agree or disagree with statements on a five-point scale. Primary data from respondents were collected using a questionnaire. Each statement on the instrument was tested for validity and reliability by using confirmatory factor analysis (CFA).

The characteristics of the population in this study are tourists who visit heritage tourism destinations, especially the Braga area and its surroundings in Bandung. Convenience sampling is defined as a technique in determining the sample related to the characteristics of a moving population with an unknown amount. The number of the respondents in this study are 271 domestic tourists comprises $57 \%$ Bandung residents and 43\% came from outside Bandung. Data processing techniques in this study consist of editing, coding, and tabulating. Meanwhile, the data analysis technique used in this research is quantitative data analysis techniques. Structural equation modeling (SEM) with the assistance of LISREL software version 8.72 was used as a data analysis procedure to test the research hypothesis. SEM is a statistical modeling technique that is highly cross-sectional, linear, and general in nature. Included in this SEM are factor analysis, path analysis, and regression analysis.

\section{RESULT AND DISCUSSION}

The results of the measurement model test for exogenous and endogenous constructs can be seen through the value of the loading factor coefficient of each indicator, the value of the construct reliability, and the variance extracted which is presented in table 1 .

Table 1 Exogenous and Endogenous Construct Measurement Models

\begin{tabular}{|c|c|c|c|c|c|c|}
\hline $\begin{array}{c}\text { LATENT } \\
\text { VARIABL } \\
\text { E }\end{array}$ & MANIFEST VARIABLE & $\lambda$ & $\lambda^{2}$ & $\mathbf{e}$ & $\mathbf{C R}$ & VE \\
\hline \multirow[t]{8}{*}{ Authenticity } & \multirow{2}{*}{$\begin{array}{l}\text { Heritage buildings here are well } \\
\text { maintained }\end{array}$} & 0,91 & 0,83 & 0,16 & 0,89 & 0,65 \\
\hline & & 5 & 7 & 3 & 4 & 1 \\
\hline & \multirow{2}{*}{$\begin{array}{l}\text { Heritage buildings here represent } \\
\text { history in the past }\end{array}$} & 0,81 & 0,67 & 0,32 & & \\
\hline & & 9 & 1 & 9 & & \\
\hline & \multirow{2}{*}{$\begin{array}{l}\text { Heritage buildings here are } \\
\text { antique }\end{array}$} & 0,92 & 0,85 & 0,14 & & \\
\hline & & 3 & 2 & 8 & & \\
\hline & \multirow{2}{*}{$\begin{array}{l}\text { The originality of the heritage } \\
\text { buildings here is still maintained. }\end{array}$} & 0,61 & 0,37 & 0,62 & & \\
\hline & & 1 & 3 & 7 & & \\
\hline \multirow[t]{4}{*}{ Walkability } & \multirow{2}{*}{$\begin{array}{l}\text { The traffic around this tourist } \\
\text { destination is pedestrian-friendly }\end{array}$} & 0,84 & 0,71 & 0,28 & 0,89 & 0,63 \\
\hline & & 5 & 4 & 6 & 3 & 0 \\
\hline & This tourist destination is & 0,88 & 0,77 & 0,22 & & \\
\hline & connected to other destinations & 0 & 4 & 6 & & \\
\hline
\end{tabular}


International Journal Of Science, Technology \& Management

\begin{tabular}{|c|c|c|c|c|c|}
\hline $\begin{array}{l}\text { This tourist destination is easy to } \\
\text { reach on foot }\end{array}$ & $\begin{array}{c}0,89 \\
7\end{array}$ & $\begin{array}{c}0,80 \\
5\end{array}$ & $\begin{array}{c}0,19 \\
5\end{array}$ & & \\
\hline Taking a walk around this tourist & 0,63 & 0,40 & 0,59 & & \\
\hline destination is safe from crime & 3 & 1 & 9 & & \\
\hline I feel comfortable walking & 0,67 & 0,45 & 0,54 & & \\
\hline around this tourist destination. & 5 & 6 & 4 & & \\
\hline I feel happy with the experience & 0,90 & 0,81 & 0,18 & 0,86 & 0,53 \\
\hline of traveling here & 1 & 2 & 8 & 8 & 3 \\
\hline $\begin{array}{l}\text { I feel that my expectations have } \\
\text { been fulfilled while traveling } \\
\text { here }\end{array}$ & $\begin{array}{c}0,66 \\
7\end{array}$ & $\begin{array}{c}0,44 \\
5\end{array}$ & $\begin{array}{c}0,55 \\
5\end{array}$ & & \\
\hline $\begin{array}{l}\text { I'm sure I made the right } \\
\text { decision to travel here }\end{array}$ & $\begin{array}{c}0,66 \\
4\end{array}$ & $\begin{array}{c}0,44 \\
1\end{array}$ & $\begin{array}{c}0,55 \\
9\end{array}$ & & \\
\hline $\begin{array}{l}\text { I have positive feelings about } \\
\text { this tourist place. }\end{array}$ & $\begin{array}{c}0,90 \\
2\end{array}$ & $\begin{array}{c}0,81 \\
4\end{array}$ & $\begin{array}{c}0,18 \\
6\end{array}$ & & \\
\hline $\begin{array}{l}\text { I have a strong intention to visit } \\
\text { here again }\end{array}$ & $\begin{array}{c}0,86 \\
7\end{array}$ & $\begin{array}{c}0,75 \\
2\end{array}$ & $\begin{array}{c}0,24 \\
8\end{array}$ & $\begin{array}{c}0,85 \\
3\end{array}$ & $\begin{array}{c}0,66 \\
0\end{array}$ \\
\hline $\begin{array}{l}\text { I intend to return to this tourist } \\
\text { destination with friends and } \\
\text { family }\end{array}$ & $\begin{array}{c}0,76 \\
1\end{array}$ & & $\begin{array}{c}0,42 \\
1\end{array}$ & & \\
\hline If it's around the location, I will & 0,80 & 0,65 & 0,35 & & \\
\hline make time to come again & 6 & 0 & 0 & & \\
\hline
\end{tabular}

$\begin{array}{llccccc}\text { Satisfaction } & \text { I feel happy with the experience } & 0,90 & 0,81 & 0,18 & 0,86 & 0,53 \\ & \text { of traveling here } & 1 & 2 & 8 & 8 & 3\end{array}$

I feel that my expectations have been fulfilled while traveling $\begin{array}{rrr}7 & 5 & 5\end{array}$

I'm sure I made the right $0,66 \quad 0,44 \quad 0,55$

Revisit

intention

$\lambda=$ factor loading value, $\mathrm{e}=\mathrm{error}, \mathrm{CR}=$ composite reliability, $\mathrm{VE}=$ variance extracted Source: Lisrel Output, Primary Data (2020)

The table above shows that the loading factor $(\lambda)$ value for each manifest variable is greater than 0.5 . This means that each manifest variable is declared valid in forming an exogenous construct. Then the construct reliability (CR) value must be above 0.7 and variance extracted (VE) must be above 0.5 , so it can be concluded that all exogenous constructs have good construct validity and reliability. As previously explained, this study applies analysis with Structural Equation Modeling (SEM) with the help of Lisrel version 8.72 software as an effort to test the hypothesis. In SEM analysis, there are two methods of using the input data matrix type, namely the variance/covariance matrix and the correlation matrix. This analysis will use the covariance matrix input for further estimation. The choice of input with a covariance matrix is because the covariance matrix has the advantage of providing valid comparisons between different populations or samples, which is sometimes not possible when using a correlation matrix model. 
International Journal Of Science, Technology \& Management

Table 2 Path Coefficient of Research Hypotheses

\begin{tabular}{llllccc}
\hline \multicolumn{4}{c}{ Hypothesis } & Estimate & Std. Error & t value \\
\hline H1 & Authenticity & $-->$ & Satisfaction & 0,423 & 0,057 & 7,437 \\
H2 & Walkability & $-->$ & Satisfaction & 0,448 & 0,058 & 7,784 \\
H3 & Authenticity & $-->$ & Revisit intention & 0,190 & 0,049 & 3,846 \\
H4 & Walkability & $-->$ & Revisit intention & 0,400 & 0,053 & 7,516 \\
H5 & Satisfaction & $-->$ & Revisit intention & 0,495 & 0,062 & 7,954 \\
\hline
\end{tabular}

The other objective of the structural model analysis is to estimate the influence parameters between variables, which will also prove the research hypothesis. The following is a summary of the results of parameter estimation from the SEM analysis that has been carried out as presented in Table 2 . The coefficient value of standardized regression weight between the authenticity and the satisfaction is 0.423 and the $t$ value is 7.437 or greater than 1.96 , then $\mathrm{H} 0$ is rejected. This means that the authenticity variable has a positive and significant effect on the satisfaction. Likewise, the standardized regression weight coefficient value between the walkability and the satisfaction is 0.448 and the $\mathrm{t}$ value is 7.784 or greater than 1.96 , then $\mathrm{H} 0$ is also rejected. This means that every unit increase in the walkability will encourage an increase of 0,448 units of satisfaction. Meanwhile, the standardized regression weight coefficient values between authenticity and walkability with revisit intention are 0.190 and 0.400 , respectively. This condition demontrates that authenticity and walkability have a positive and significant effect on revisit intention in which the t value of the two relationships between these variables are 3,846 and 7,516. Meanwhile, the standardized regression weight coefficient value between the satisfaction and the revisit intention is 0.495 greater than 1.96 and $t$ value of 7.954 which explains the rejection of $\mathrm{H} 0$. This means that the variable increase for every unit of the satisfaction has an impact on an increase of 0,495 units of the revisit intention.

To test the significance of satisfaction as a mediating variable in the model, it can be checked from the Sobel test with the first details being to find the path coefficient (estimate) value and standard error for each path. Based on the results of the calculation, the $t$ value for testing the effect of mediation on the sixth hypothesis (H6) is 5.436 greater than the $t$ table (1.96) with a significance level of 0.05 . It can be concluded that satisfaction is able to mediate between authenticity and revisit intention. Thus H0 is rejected. Meanwhile, the $\mathrm{t}$ value for testing the effect of mediation on this last hypothesis $(\mathrm{H} 7)$ is 5.551 greater than the table (1.96) with a significance level of 0.05. Therefore, it can be explained that satisfaction is able to mediate between walkability and revisit intention which represents the rejection of $\mathrm{H} 0$.

The results of the goodness of fit model test in which the goodness of fit criteria of the structural equation model above is presented in table 3 . Based on the 
criteria, it can be seen that most of the modified research models have a good fit test in which the majority have good criteria (good fit model).

Table 3 Goodness of Fit Model Test

\begin{tabular}{ccccc}
\hline No. & $\begin{array}{c}\text { Goodness Of Fit } \\
\text { Index }\end{array}$ & Cut-Off Value & Result & Conclussion \\
\hline 1 & RMSEA & $\leq 0,08$ & 0,062 & Good Fit \\
2 & GFI & $\geq 0,90$ & 0,921 & Good Fit \\
3 & AGFI & $\geq 0,90$ & 0,882 & Marginal Fit \\
4 & RFI & $\geq 0,90$ & 0,968 & Good Fit \\
5 & NFI & $\geq 0,90$ & 0,976 & Good Fit \\
6 & CFI & $\geq 0,90$ & 0.988 & Good Fit \\
7 & NNFI & $\geq 0,90$ & 0,984 & Good Fit \\
8 & IFI & $\geq 0,90$ & 0,988 & Good Fit \\
\hline
\end{tabular}

The results of this study are useful for stakeholders who have a direct and indirect relationship with the world of tourism in Bandung, especially in the field of heritage tourism. Hypothesis test results demonstrate that authenticity has a positive and significant effect on tourist satisfaction in the Braga and Asia Afrika area, which is one of the historic iconic areas in the center of Bandung. Thus, stakeholders need to pay more attention $t$ to maintain the authenticity of historical buildings in the area. The efforts that can be made by stakeholders are to maintain the building consistently and let the building look like the original so that it has an antique impression. This effort will have an impact on the increasing historical value of buildings based on tourist perceptions. The stronger the impression of tourists about the authenticity of the historic buildings in the area, it will cause a feeling of pleasure which is a manifestation of perceived satisfaction. The perceived authenticity of historical buildings can also shape the feeling of pleasure of tourists associated with the assumption that the decision taken to travel in the area is right. It also means that all the expectations of tourists have been fulfilled from the needs that arise in them, word of mouth, promotion of travel and tourism organizers, and the campaign of the Bandung Government. The support of empirical data on the hypothesized relationship between the authenticity of historical buildings and tourist satisfaction also explains that the results of this study also establish the theory used as a basis for developing this hypothesis. The findings of this study support [13]. The results of this study are also in line with the findings of $[4 ; 9 ; 19]$ who stated that authenticity has a positive effect on tourist satisfaction. In addition, these findings complement what has been found by previous researchers in which hypothesis testing the relationship between concepts is supported by empirical data with different objects. [9;19] focuses on research objects in the form of cultural heritage tourism, while [23] research's object is urban tourism. In the other hand, the research object chosen by [28] is working-holiday tourism. 
This study also found that authenticity had a positive and significant direct effect on the revisit intention of tourists visiting the Braga and Asia Africa areas. Likewise, the satisfaction of tourists after feeling the atmosphere of the authenticity of historical buildings in the area positively and significantly influences their willingness to return to these destinations. That is, authenticity has an effect both directly and indirectly through tourist satisfaction on revisit intention. Therefore, improving the quality of the design of the strategy to maintain the authenticity of the historic buildings in the area cannot be ignored. Maintaining the authenticity of the area can increase the desire of tourists to visit again and even influence their desire to recommend the destination to the closest reference group such as family and close friends. The results of this study support the findings of [28] which suggest that interest in returning to visit is positively influenced by tourist satisfaction. These findings are also in line with the results of research by [33] that states tourist satisfaction has a significant positive effect on interest in returning to visit. Likewise, [34] research results are reinforced by the findings of this study.

Meanwhile, [14] found that walkability also plays an important role in increasing the marketing success of a tourist destination. The results of hypothesis testing in this study describe all walkability indicators have an important role in increasing tourist satisfaction and the revisit intention of tourists visiting the Braga and Asia Africa areas. Therefore, the attention of related stakeholders needs to be focused on efforts to maintain the supporting infrastructure properly. So far, tourists consider that the area is pedestrian-friendly, connected to other destinations, easy to reach, safe, and comfortable for pedestrians. Based on the results of the Sobel test in this study, illustrates that both authenticity and walkability have a positive and significant indirect effect on revisit intention through tourist satisfaction. This means that the steps taken by stakeholders in understanding what tourists expect are critical. The expectation of tourists can be formed by a promotional program carried out by tourism service providers in the area. However, maintaining the authenticity of historical buildings and maintaining the quality of walkability are also important tasks of the Bandung Government. Therefore, the cooperation between the two parties is very important in shaping the position of the area in the minds of tourists so as to form proportional expectations according to the facts. The efforts made by all stakeholders in fulfilling tourists' expectations are aimed at shaping their satisfaction which will encourage their interest in revisiting the area in the future.

\section{CONCLUSION}

This study aims to test the proposed hypothesis based on a theory that connects several concepts developed by scientists in the fields of marketing, architecture, and planning in the context of tourism. The combination of conceptual relationships involving different disciplines is a prominent strength of this study. Authenticity is a 
concept that is more widely used in the scientific domain. Research on authenticity is mostly carried out using a qualitative approach which is intended to describe the authenticity attributes of buildings that contain historical values. As well as walkability, the concept is more widely used in studies from the disciplines of urban planning. Generally, research on walkability places more emphasis on measuring the quality of infrastructure in the form of sidewalks or pedestrians and the atmosphere around pedestrians for residents of a city. Walkability is also often associated with the satisfaction level of the inhabitants of a city in previous studies. This study offers the idea both the measurement of the concept of authenticity and walkability can also be applied to the field of tourism destination marketing which integrates the two functions at the same time. The choice of heritage tourism as an object in this research is considered appropriate in relation to the characteristics of tourist behavior, who generally want comfort while enjoying historical buildings in an area. The tourists expect to have a real view of the historical building's authenticity and also a comfortable atmosphere while appreciating these objects. Thus, these two concepts are operationalized by adjusting the characteristic attributes of the object and population in this study to keep each item on the research instrument valid in the context of the content. This research also opens new horizons about measuring the role of these two concepts in other areas that are still related to cultural heritage both at the national and international levels. In addition, further research can focus more on sample groups with more homogeneous characteristics both in the context of geographic and demographic backgrounds. The idea is intended to facilitate heritage tourism marketers in creating and communicating value to their target market. In general, successful marketing begins with the process of selecting the right value in the form of market segmentation, targeting target markets, and positioning the image of a tourist destination correctly.

This study illustrates that authenticity and walkability have a positive and significant effect on tourist satisfaction that impacts their interest in revisiting to the Braga and Asia Africa area in the future. This provides a very clear picture for the Regional Government of Bandung as the main stakeholder to select, create, and communicate the right value in marketing the city. So far, a comprehensive review may be needed in choosing the right value in the form of strategic steps in segmenting tourists, establishing profitable tourist segments, and positioning Bandung heritage tourism in the minds of the public. Determining the right tourists will make it easier for stakeholders to identify their needs and desires in visiting Bandung, especially in order to appreciate cultural heritage which is one of the mainstays of tourism in the city. The findings of this study are to identify what causes tourists to feel satisfied and eager to revisit these tourist destinations in the future. In the short term, stakeholders can focus their resources on efforts to maintain the attributes attached to historical buildings and pedestrians in the area that are considered positive by tourists. The attributes of historical buildings in the area that need attention based on their authenticity include their historical value, antiquity, authenticity, and maintenance. Meanwhile, comfort, 
whereabouts, ease of access, connection with other destinations, and friendliness for pedestrians are important elements that need to be improved based on the aspect of walkability. The findings of this study confirm that improving the quality of all the authenticity and walkability attributes of the research object will have an effect on increasing tourist satisfaction. Meanwhile, the level of interest in visiting again is positively influenced by tourist satisfaction after visiting these destinations.

Future studies are suggested focusing on the sample group with more homogeneous characteristics both in the context of geographic and demographic backgrounds. The idea is intended to facilitate heritage tourism marketers in creating and communicating value to their target market. In general, successful marketing begins with the process of selecting the right value in the form of market segmentation, targeting target markets, and positioning the image of a tourist destination correctly. The city of Bandung has many cultural heritages related to history and education that are interesting to be used as objects of research in the future. The next researcher can also develop his conceptual model by adding relevant variables to be measured which contribute to the formation of satisfaction and revisit intention of the tourists.

\section{ACKNOWLEDGMENTS}

Deep gratitude goes to the institution of research and community services of the University of Jenderal Achmad Yani that has provided funding support to create research that is beneficial for the development of science and tourism marketing practices.

\section{REFERENCES}

[1] Prayag, G., \& Ryan, C., Antecedents of Tourists' Loyalty to Mauritius The Role and Influence of Destination Image, Place Attachment, Personal Involvement, and Satisfaction, Journal of Travel Research, 51(3), 2012, pp. 342-356.

[2] Loureiro, S. M. C., The role of the rural tourism experience economy in place attachment and behavioral intentions, International Journal of Hospitality Management, 40, 2014, pp. 1-9.

[3] Shonk, D. J., \& Chelladural, P., Service quality, satisfaction, and intent to return in event sport tourism, Journal of Sport Management, 22(5), 2008, pp. 587-602.

[4] Park, J. Y., Bufquin, D., \& Back, R. M., When do they become satiated? An examination of the relationships among winery tourists' satisfaction, repeat visits and revisit intentions, Journal of Destination Marketing and Management, 11, 2019, pp. 231239.

[5] Cong, L. C., A formative model of the relationship between destination quality, tourist satisfaction and intentional loyalty: An empirical test in Vietnam, Journal of Hospitality and Tourism Management, 26, 2016, pp. 50-62.

[6] Choo, H., Ahn, K., \& Petrick, J. F., An integrated model of festival revisit intentions: Theory of planned behavior and festival quality/satisfaction. International Journal of Contemporary Hospitality Management, 28(4), 2016, pp 818-238. 
[7] Bonn, M. A., Line, N. D., \& Cho, M., Low gasoline prices: The effects upon auto visitor spending, numbers of activities, satisfaction, and return intention, Journal of Travel Research, 56(2), 2017, pp. 263-278.

[8] Park, E., Choi, B. K., \& Lee, T. J., The role and dimensions of authenticity in heritage tourism. Tourism Management, 74, 2019, 99-109.

[9] Park, S. Y., Hwang, D., Lee, W. S., \& Heo, J., Influence of nostalgia on authenticity, satisfaction, and revisit intention: The case of Jidong mural alley in Korea, International Journal of Hospitality and Tourism Administration, 21(4), 2020, pp. 440-455.

[10] Castéran, H., \& Roederer, C., Does authenticity really affect behavior? The case of the Strasbourg Christmas Market, Tourism Management, 36, 2013, pp. 153-163.

[11] Meng, B., \& Choi, K., An investigation on customer revisit intention to theme restaurants: the role of servicescape and authentic perception, International Journal of Contemporary Hospitality Management, 30(3), 2018, pp. 1646-1662.

[12] Rani, Z. M., Othman, N., \& Ahmad, K. N., Perceived Authenticity as a Determinant to Revisit Heritage Tourism Sites in Penang, Journal Tourism, Leisure, and Global Change, 1, 2014, pp. 22-24.

[13] Zhang, H., Cho, T., Wang, H., \& Ge, Q.. The influence of cross-cultural awareness and tourist experience on authenticity, tourist satisfaction and acculturation in World Cultural Heritage Sites of Korea. Sustainability, 10(927), 2018, pp 1-14.

[14] Hall, M. \& Ram Y., Shoval N., The Routledge International Handbook of Walking, Routledge, 2018.

[15] Grasser G., Titze S., Stroneger W. J., Are residents of high-walkable areas satisfied with their neighbourhood?, Journal of Public Health, 24, 2016, pp. 469-476.

[16] Truong, T. L. H., Lenglet, F., \& Mothe, C., Destination distinctiveness: concept, measurement, and impact on tourist satisfaction, Journal of Destination Marketing and Management, 8, 2018, pp.214-231.

[17] Dominguez-Quintero A. M., Gonzales-Rodriguez M. R., Roldan J. L., The role of authenticity, experience quality, emotion, and satisfaction in a cultural heritage destination, Journal of Heritage Tourism, 14(5-6), 2019, pp 491-505.

[18] Meng Z., Cai L., Day J., Tang C., Lu Y., Zhang H., Authenticity and nostalgia-subjective well being Chinase rural-urban migrant, Journal of Heritage Tourism, 14(5-6), 2019, pp 506-524.

[19] Gao, J., Sonia, S., \& Zhang, C., Authenticity, involvement, and nostalgia: Understanding visitor satisfaction with an adaptive reuse heritage site in urban China. Journal of Destination Marketing \& Management, 15, 2020, 100404.

[20] Rehman, A., Ahmed, M. A., Mahmood, F., Shahid, M., \& Sciences, A., The effects of brand experience, satisfaction and trust on brand loyalty: an empirical research on the internet services of cellular companies in Pakistan, International Journal of Management Sciences and Business Research, 3(9), 2014, pp. 90-100.

[21] Wang C., Liu J., Wei L., Zhang T., Impact of tourist experience on memorability and authenticity: a study of creative tourism, Journal of Travel \& Tourism Marketing, 37(1), 2020, pp 48-63.

[22] Meng, F., Tepanon, Y., \& Uysal, M., Measuring tourist satisfaction by attribute and motivation: The case of a nature-based resort, Journal of Vacation Marketing, 14(1), 
2008, pp. 41-56.

[23] Khanon S., Moyle B., Scott N., Kennelly M., Host-guest authentification of intangible cultural hertage: a literature review and conceptual model, Journal of Heritage Tourism, 14(5-6), 2019, 396-408.

[24] Kelly, C. E., Tight, M. R., Hodgson, F. C., \& Page, M. W., A comparison of three methods for assessing the walkability of the pedestrian environment, Journal of Transport Geography, 19(6), 2011, pp. 1500-1508.

[25] Forsyth, A., \& Southworth, M. (2008). Cities afoot-Pedestrians, walkability and urban design, Journal of Urban Design, 13(1), 2008, pp. 1-3.

[26] Moura, F., Cambra, P., \& Gon,calves, A. B., Measuring walkability for distinct pedestrian groups with a participatory assessment method: A case study in Lisbon. Landscape and Urban Planning, 187, 2017, pp. 282-296.

[27] Arslan, S., A probe into the indicators of intercultural communicative competence in an EFL self-study textbook. International Online Journal of Education and Teaching (IOJET), 5(1), 2018, pp. 150-167.

[28] Meng, B., \& Han, H., Working-holiday tourism attributes and satisfaction in forming word-of-mouth and revisit intentions: Impact of quantity and quality of intergroup contact, Journal of Destination Marketing and Management, 9, 2018., pp. 347-357.

[29] Abubakar, A. M., Ilkan, M., Meshall Al-Tal, R., \& Eluwole, K. K., eWOM, revisit intention, destination trust and gender. Journal of Hospitality and Tourism Management, 31, 2017, pp. 220-227.

[30] Wibowo, S. F., Sazali, A., \& Kresnamurti R. P., A., The Influence of destination image and tourist satisfaction toward revisit intention of Setu Babakan Betawi Cultural Village, Jurnal Riset Manajemen Sains Indonesia, 7(1), 2016, pp 136-156.

[31] Kaur, G., \& Quareshi, T. Q., Factors obstructing intentions to trust and purchase online products, Asia Pacific Journal of Marketing, 27, 2015, pp. 758-783.

[32] Chang, L. L., Backman, K. F., \& Huang, Y. C., Creative tourism: a preliminary examination of creative tourists' motivation, experience, perceived value and revisit intention, International Journal of Culture, Tourism, and Hospitality Research, 8(4), 2014, pp. 401-419.

[33] Foroudi, P., Akarsu, T. N., Ageeva, E., Foroudi, M. M., Dennis, C., \& Melewar, T. C., Promising the dream: changing destination image of London through the effect of website place, Journal of Business Research, 83, 2018, pp. 97-110.

[34] Moon, H., \& Han, H., Destination attributes influencing Chinese travelers 'perceptions of experience quality and intentions for island tourism: a case of Jeju Island, Tourism Management Perspectives, 28, 2018, pp. 71-82. 